Gramáticas de la (¿post?) violencia:

identidades, guerras, cuerpos y fronteras

\title{
Our dead and disappeared: reflections on the construction of the notion of political disappearance in brazil
}

\author{
Desirée de Lemos Azevedo' \\ 1 Universidade Federal de São Paulo, \\ Programa de Pós-graduação em Ciências Sociais, São Paulo/SP, Brasil
}

\begin{abstract}
Based on ethnographic and documentary material, this article analyzes the social construction of political disappearance in Brazil. It argues that less than a phenomenon to be captured from reality, it is a category produced in and a producer of a social field, a point of convergence of debates and actions of actors and institutions. The objective is to show the discourses that function as truths about the phenomenon in Brazil, as well as the methods, procedures, forums and disputes by which they are sanctioned as such. It also addresses the intrinsic relation of this process with the production of political communities by focusing on the discourse of the movement of families of the killed and disappeared political actors. In conclusion, it points to some social implications that result from delimiting what is politically relevant violence.
\end{abstract}

Keywords: Disappearance; memory; human rights; victims. 


\section{Os nossos mortos e desaparecidos: reflexões sobre a construção da noção de desaparecimento político no brasil}

\section{Resumo}

A partir de material etnográfico e documental, o presente artigo analisa a construção social do desaparecimento político no Brasil. Argumenta que menos do que um fenômeno a ser auferido da realidade, trata-se de uma categoria produzida em e produtora de um campo social, um ponto de convergência de debates e ações de atores e instituições. O objetivo é mostrar os discurso que funcionam como verdadeiros acerca do fenômeno no Brasil, bem como os métodos, procedimentos, instâncias e disputas por meio dos quais eles são sancionados enquanto tais. Aborda ainda a relação intrínseca desse processo com a produção de comunidades políticas, ao destacar a centralidade enunciadora do movimento de familiares de mortos e desaparecidos políticos. Na conclusão, aponta algumas implicações sociais resultantes da delimitação de uma violência politicamente relevante.

Palavras-Chave: Desaparecimento; Memória; Direitos Humanos; Vítimas. 


\section{Our dead and disappeared: reflections on the construction of the notion of political disappearance in brazil}

Desirée de Lemos Azevedo

\section{Virgílio}

On the morning of November 2, 2012, the Ecumenical Act in Memory of the Dead and Disappeared during the dictatorship (1964-1985) was held at the Ricardo de Albuquerque Cemetery in the northern zone of Rio de Janeiro. As part of my research ${ }^{1}$ with the families of people considered to be victims of political deaths or disappearances, ${ }^{2}$ I attended the event at the cemetery in the company of Victoria Grabois, then president of Grupo Tortura Nunca Mais/RJ [the Torture Never Again Group] and one of the event organizers. ${ }^{3}$

The date of the event, All Soul's Day, is an important moment on the political agenda of the movement of families, a day when the militants hold demonstrations in cemeteries where bodies of victims of the dictatorship had been hidden. As the state now recognizes, during that period, a policy of disappearance was conducted, sometimes involving joint action between municipal funeral services, coroners offices and the repressive forces (CNV 2014). ${ }^{4}$ The disappearances involved combining illegal acts with the routines conducted by these institutions when handling cadavers considered to be those of 'the indigent,' those considered unidentified, or those buried by the state when no one claims the body (Ferreira 2007).

During years of searching, the movement discovered bodies of the disappeared buried anonymously in public cemeteries without the knowledge of their families. Some were transferred to common graves. These were collective burial sites located alongside cemeteries and generally seen by society as unimportant sites used for the deceased who were unmourned by anyone and treated as though they had no value. For this reason, each year the movement goes to cemeteries to conduct an act that is both political and emotional, as part of its struggle to denounce this policy of disappearance, rescue their dead relatives from invisibility, publicize their memories and collectivize their mourning. A few years ago at the Ricardo de Albuquerque Cemetery, they were able to erect a monument at the spot where an unregistered common grave was found

\footnotetext{
Conducted between 2012 and 2015, the ethnographic study resulted in a doctoral thesis defended in the Graduate Program in Social Anthropology at Unicamp. This article revisits the reflection on the construction of the category of political disappearance developed in the thesis, particularly in the third chapter, considering questions that I have explored in postdoctoral studies concerning the identification by the Grupo de Trabalho Perus of the bones of disappeared political activists. I would like to thank Liliana Sanjurjo and the anonymous reviewers from Vibrant for their critical readings and valuable contributions.

2 Hereinafter, the collective formed by the various organizations and actors inserted in political arenas based on the affirmation of kinship ties with people who were killed and disappeared during the dictatorship, and presenting demands to the state, will be called the movement of families.

3 The Grupo Tortura Nunca Mais/RJ is an organization formed by victims and family members of victims of the dictatorship. It was responsible for locating a secret grave at the Ricardo de Albuquerque Cemetery, and for the documentation showing that 14 people that the group had been searching for were buried at the site. Victória Grabois participated in the resistance to the dictatorship. Her father, brother and first husband were disappeared by the Brazilian Army in the region of Araguaia, in 1973.

4 During the dictatorship, political activities were monitored and repressed by a broad network of civil and military intelligence and security agencies. At first the security actions, that is those of direct combat against the enemies of the regime, were conducted by the political police and the armed forces. The former mainly through the Political and Social Police (Delegacias de Ordem Politica e Social: DOPS), which was created before the dictatorship; the latter through three military agencies: the CIE of the army, the CISA of the air force and the CENIMAR of the navy. After 1970, the army created the DOI-CODIs, which became the main and most lethal repressive agent in Brazil.
} 
containing two thousand skeletons. Today, the location has an ossuary flanked by fourteen mirrors that represent tombstones. In front of them, each year family members pay homage to fourteen disappeared political activists who had also been buried in this common grave.

The reflections proposed for this article began in the sensitive environment of this act, triggered amid the pain, music, prayers, denunciations and requests for justice. The environment also included the presence in solidarity of family members of the victims of police violence since the end of the dictatorship, under democratic governments. These are members of humble families, who during the act spoke of their struggle to have their losses recognized as political too. To hear their words, and to observe my own image and that of both groups of families indistinctly reflected by the mirrored tombstones, provoked in me an inevitable sense of identification. This led me to think that during the dictatorship any person could have been the target of disappearance. Thus, the monument appeared to denounce a system of violent acts that affected the whole of society, although in different ways that are not completely understood. Yet, soon after, as I looked at the inscriptions that recorded the names and political organizations to which the 14 people being homage also belonged, I realized that the monument also marked distinctions. There were certain victims and a certain kind of violence to which it gave special attention.

There was a dynamic movement of approximations and distancings among different types of violence and victims at the event. But, although it may have seemed that this dynamic was explicit in the interaction of the act with the monument, in reality, it was something that occurred at the end of the event had me reconsider. I refer to the curious approach of an older women who was paying homage to her mother, who was buried in a single grave close to the common one. After I explained what we were doing there, she told me she knew the history very well, because her father had participated in demonstrations against the coup of 1964. The increased repression inhibited him from continuing, but her cousin Virgilio "got involved in politics." One day Virgílio left home without ever returning or sending news. She said she was pleased with the proximity between the monument and the grave of her mother, who liked her nephew very much, because it was as though they are now together. From then on, she decided she would take them flowers as well.

Hearing her story troubled me. Particularly because of the way that she related the monument to her missing cousin, without, however, affirming that his absence was a political disappearance. In reality, she ignored me or did not understand when I asked if he was or was not a victim of political disappearance. I repeated the question, thinking that she might be a relative of the famous Virgilio Gomes da Silva, ${ }^{\text {bbut }}$ this was a different Virgilio. I was disturbed by the possibility of being faced with a "new case" and tried to convince her to speak with Victória. She refused. Only then, standing in front of the monument, did I look more closely at the list of the disappeared and the dates that they had gone missing: three people in 1971, five in 1972 and six in 1973. Is it possible that they were the only ones among those murdered by the repressive forces in the city to be buried there in those years? Why was it that only 14 of the two thousand people buried in a secret grave had been considered political disappearances, while Virgilio - the young man who conducted daily activities in opposition to the dictatorship and disappeared without trace - did not have the same recognition?

A few days went by before I realized that something was wrong with my surprise. If disappearance is characterized precisely by the lack of information, then should it not be normal for there to be a lack of control over the universe of the disappeared and thus the discovery of new cases? I then realized that this is not the most common perception about political disappearance in Brazil. Different from Argentina,

\footnotetext{
5 Virgílio Gomes da Silva participated in the kidnapping of US Ambassador Charles Elbrick, who was exchanged for the release of 15 political prisoners in 1969. Illegally jailed, Virgílio disappeared. He is the only Virgílio recognized as a political disappearance, and is also considered to be the first registered case of political disappearance (Almeida 2009).
} 
where the data that is most accepted and promoted is based on estimates, which indicate the scope of the phenomenon and the incomplete character of the information, in Brazil, the different actors involved with the theme only disclose precise data, suggesting a phenomenon that is not only restricted, but also grasped in its totality and in the individualities that constitute it. ${ }^{6}$

If there are distinct truths about disappearance in the different societies in which its practice is identified, it seems to me to be important to understand the processes on which these truths are based, instead of taking them as given. By trying to determine the roots of my disturbance, I realized the importance of placing in perspective the view of political disappearance shared by those who denounce it. 7 This means no longer observing political disappearance as a condition found in a given historic reality and considering it instead as a category that is produced in and a producer of a social field (Bourdieu 2011), a point of convergence of debates and actions of actors and institutions that are constituted around a regime of truth (Foucault 2007). Based on this approach, this article explores the discourses that function as truths about the phenomenon in Brazil, seeking to show the methods, procedures and instances by means of which they were sanctioned as such. It also looks at the intrinsic relation of this process with the production of political communities, by highlighting the centrality of the voice of the movement of families. In the conclusion, I point to some social implications of the delimitation of a politically relevant violence.

\section{Similar events, different phenomena}

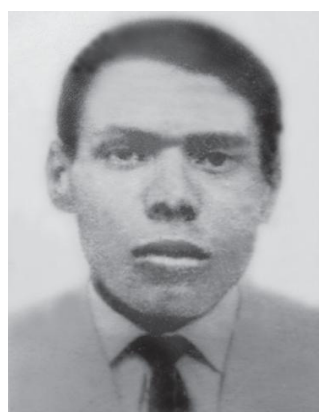

\section{Abílio Clemente Filho}

Son of Maria Helena Correa and Abílio Clemente. Studied at the State School Fernão Dias Paes, in the city of São Paulo. When he disappeared, he was in the $4^{\text {th }}$ year of the social sciences course at the State University of São Paulo (UNESP) and was active in the student movement in Rio Claro, (SP). When he disappeared, he was with a friend on the beach of José Menino, in Santos (SP). That year, he was honored at the graduation ceremony of his college.

In the process analyzed by the Special Commission on Political Deaths and Disappearances (CEMDP) there is a report in attachment by Maria Amélia de Almeida Teles, of the Commission of Families of the Political Dead and Disappeared, informing that in the Public Archives of São Paulo State, among documents of the now extinct Department of Political and Social Order of São Paulo (DOPS/SP), they found school records of Abilio Clemente Filho from the time he was in high school. According to the police records, this file had been found at the residence of Ishiro Nagami, a militant of the Ação Libertadora Nacional [National Liberation Action] (ALN) who was killed with Sérgio Corrêa, on September 4, 1969, when the car exploded in which both were traveling on the Rua da Consolação, in the São Paulo capital. Joana D’Arc Contijo told Maria Amélia, both of whom were jailed in the Detachment of Operations and Information - Center of Operations for Domestic Defense of São Paulo (DOI-CODI/SP) at the time, who said that she had heard the screaming of a young man all night

\footnotetext{
6 Despite the list of 9,334 people indicated by the Comisión Nacional sobre la Desaparición de Personas, [National Commission on the Disappearance of People] in Argentina the current understanding is that these are only the cases that have been denounced. Human rights organizations have publicized the number of 30 thousand disappeared, which is a projection of the cases that have not been denounced. In Brazil, estimates of the total number of disappeared are not published, only the precise numbers and lists of names.

7 I accompany Taussig's (1995) criticism of the possibility of understanding the uses of violence in strictly rational terms. According to Taussig, this activity is the role of social actors who intend to systematize an explanation and struggle against the discourses (and silences) that support a culture of terror. The alternative approach would be a reflection that would go beyond the content of these discourses, observing the forms that they assume to acquire effects of truth (Foucault 2007).
} 
long, on the same day as Abilio's arrest. Joana believes that the youth stopped screaming because he had died. She tried to find out the identity of the victim of that torture, but was not able to. Maria Amélia said that in the mid 1990's she was approached by Abilio's sister to report his disappearance before passage of laws for indemnification.

Abilio's case was initially examined by the Commission for the Indemnification of Political Prisoners of São Paulo and was accepted. The commission found that based on the evidence presented and on the knowledge accumulated about the procedures of the organs of political repression, it was possible to conclude that Abilio Clemente Filho disappeared for political reasons. The rapporteur of the case for the Special Commission on Political Deaths and Disappearances (CEMDP), Belisário dos Santos Júnior, voted in favor of granting the request, adding: "In addition, in this federal entity, with all of the evidence collected well considered, I understand that Abilio, who was a political militant, whose documents were seized in the residence of a person linked to armed activities, who disappeared on a certain day and whose friends and family always claimed was another victim of the political police, can and must be recognized as a person who disappeared for political reasons. To demand more proof would be to ignore the history of repression in Brazil." A São Paulo state deputy, Antônio Mentor, also made a statement to the Special Commission confirming his disappearance and his militancy in the clandestine organization during the dictatorship. The case was approved unanimously.

Source: Dossiê Ditadura: Mortos e Desaparecidos Políticos no Brasil 1964-1985.

Involved in politics, Virgilio left home and never returned. The student activist Abilio was never seen again after a trip to Santos. Nothing more was known at the time about his destination or whereabouts. More than four decades later, nothing more has been discovered. But while these two absences were equally abrupt and enigmatic, they represent two entirely distinct social phenomenon. While Abilio is actively sought and honored in the memories of the resistance to the dictatorship, Virgilio remains only in the memory of his family members. While Virgilio's story does not permit any conclusion, including any return, Abilio's story, by contrast, offers certainty. Virgílio is a disappeared person. One of those who, as the popular anecdotes tell, "went to buy cigarettes and never returned." Abilio is dead. His disappearance was political.

A disappearance is only the absence of a person and any information about their location, with nothing to determine the existence of violence at its origin. In principle, disappeared people may be fatal victims of crimes, but also of accidents, or natural catastrophes. They may have been legally buried as unidentified persons, they may be living and unable to communicate, or simply may not want to be found after escaping or abandoning their home, among other possibilities. Despite the range of possibilities, unexplained absences are equally experienced as disappearances by those searching for missing persons, and are communicated as such to the institutions responsible for registering them, clarifying them and/or resolving problems that they involve. For this reason, there are various studies that explore the disappearances as the irremediable encounter between human drama and the institutional actions that they provoke. ${ }^{8}$ Placed in perspective, they show us that the need to address uncertainties is a common trait to the different forms of classifying absences, generating disconcertion in the processes that involve their public denomination, recognition and administration.

In the words of Ferreira (2011), whose thesis focuses on the broad range of situations contemporarily reported as disappearance in the police stations of Rio de Janeiro, "the designation of facts and experiences as disappearance is constituted by questionings and uncertainties" (Ferreira 2011: 3). The ambiguity of the facts raises various difficulties for the agents involved, implying the non-existence of regulations and

8 For example: Ferreira 2011, Araújo 2012, Vecchioli 2001, Catela 2001. 
specific guidelines, which complicates the elaboration of policies for confronting the disappearances and assigning responsibilities. For this reason, along the different points of the institutional chain dedicated to the phenomenon, the actors regularly ask: "what does it mean for someone to disappear?" If at some of these points, it is considered as a grave and disregarded social problem, in others, such as the police stations, where its institutional trajectory usually begins, the concrete cases are treated as ordinary situations. Because they do not correspond to a specific crime, it is still belittled as something that does not amount to a 'police matter,' only a 'family' issue.

But if the violence is instigated by the police to mark the limit of their action in these cases (Ferreira 2013), it is also a category commonly used to distinguish types of disappearance. Far from being a family problem, a so-called enforced disappearance is considered a human rights violation by international law and a crime against humanity when practiced systematically. According to conventions of the United Nations and the Organization of American States on the theme, enforced disappearance is a deprivation of liberty, perpetrated directly by the state or with its compliance, followed by a refusal to admit this privation or to provide information about a person's whereabouts. Although not defined under Brazilian law, ${ }^{9}$ the phenomenon is understood to be growing in the country, considered as "a practice from the repertoire of the language of urban violence" (Araújo 2012: 31), which, through its recurrent relation to the war on drugs and the consequential disputes between police, militia and drug traffickers, has a disproportional incidence in the impoverished territories of large cities. Although these elements set clear contours, in examining the network of actors and institutions dedicated to this phenomenon in Brazil, Araújo (2012) also mentions uncertain situations that strongly resist classification.

This occurs because although the ambiguities shift from the general to the particular in enforced disappearances, they still continue to exist. The fleeting aspect only appears to dissipate when we discuss enforced disappearance at a categorical level. Yet when asking "is this a case of enforced disappearance?" the uncertainties once again surface. As Araújo shows, as strong as the indications may be, these cases constantly become targets of mistrust and silencing. From an institutional perspective, this takes place both because of the lack of legal classification, and because of the common involvement of the police forces themselves in these crimes. This is combined with the fact that the accounts available are fragmented by doubts and fear, as well as the stigma related to the population of the urban periphery - who are especially susceptible to enforced disappearance and who during the democratic period have been considered as a potential enemy through the validation of a war metaphor (Leite 2012) to justify state violence as a solution to the so-called "public security problem." This stigma leads to the relativization of violence by questioning the moral status of the victims who are often, justifiably or not, linked to criminality. These elements facilitate the immersion of the cases in a gray zone of occurrences considered to be common and insignificant and for which police action is perceived neither as responsible (Araújo 2012), nor even as pertinent or effective (Ferreira 2013).

It is interesting to note that both Araújo and Ferreira mention political disappearance as a counterpoint, presenting it as less ambiguous because it has a broader and established set of identifiable reference points. In fact, in the arenas where it is debated, the modality is usually considered to be precise and well-established. On the other hand, considering the story of Virgilio, it seems to me essential to understand what these marks are, to then raise the problem to the point that the ambiguities and uncertainties can be excluded.

\footnotetext{
9 The Inter-American Convention on the Forced Disappearance of Persons (OAS 1994) and the International Convention for the Protection of All People from Enforced Disappearance (UN 2006) were signed and ratified by Brazil. Nevertheless, enforced disappearance has still not been defined in Brazilian law, as is required in principle for adherents to the treaty. For this reason, the disappearances are indistinctly classified in police stations. In thesis, the proof of violence at the origin of the case would lead to substituting this classification for others, such as kidnapping, homicide or concealment of a body.
} 
Nevertheless, regardless of the cause, the absence of a person from the locations where they are typically expected to be found is a disconcerting event. If it causes disruption in the daily lives of those who feel it, on the other hand, it also inaugurates new routines in which dealing with the uncertainties comes to constitute an attempt at domestication (Das 1995), establishing relations between families and state institutions. These are the actors who will classify the absences according to available categories, amid processes that have countless variables but that engender shifts from the peculiarity of facts to the generality of procedures and languages. It is in this sense that a political disappearance is not the same as an enforced disappearance. While the later does not take the form of a domestic legal category, political disappearance is established and mobilized by certain state institutions. In its various daily uses, a set of markers operate in various dimensions.

\section{Dimensions of the political}

The first and most notable of the reference points is disappearance's association with death, insofar as the two words - nearly always inseparable - compose a single term: political deaths and disappearances. Undoubtedly the result of a criminal act, a political disappearance is a kidnapping followed by homicide and hiding of the body against "people who have participated, or who are accused of participation, in political activities, from September 2, 1961 until October 5, 1988, and who, for this reason, had been detained by public agents" (Art. 1ํ, Law № 9.140/95). We can observe, therefore, that the legal parameters make an attempt at precision, defining the act, the victims, the victimizers and the temporality in which they are inscribed. The so-called Law of the Dead and Disappeared, in addition to reducing the broad universe of cases to those linked to a specific act of violence (murder and hiding of the corpse), presumes a second form of clarification based on the distinction between the present and past. By this means, the phenomenon is determined as a closed historic episode, which means that we are also considering a mnemonic category, a reference to the constitution of the memorable (Candau 2011) about the dictatorship, and no less importantly, about the demarcation of its contrasts with democracy.

Like forced disappearance, therefore, political disappearance is a term coined to simultaneously circumscribe an experience of extreme violence and project a denunciation. In common, they both evoke the set of global processes that mark the twentieth century as a period of overlapping between the emergence of the large utopian narratives and catastrophes of proportions never before seen (Hobsbawm 1994). In Europe, as in America, via different though related processes, the political transition to the twenty-first century brought demands for both a "non-repetition of the past" and a "settling accounts with the past," which became important commitments of the international community that emerged with the end of the Cold War (Torpey 2006). But while in the international sphere, notions such as human rights violations and crimes against humanity highlight state responsibilities in relation to the past, present and future, Brazil began its adherence to humanitarian premises by dissociating these two domains.

The country signed up to this global commitment following the end of the dictatorship, with the enactment of a new constitution and a progressive adhesion to international agreements. This movement did not signify, however, the overturning of what is considered the centerpiece of Brazil's political transition, the Amnesty Law. Still in vigor, this law determines that the violence committed by the state involved "political crimes," as did the acts committed by those who fought the regime, and both were pardoned. In flagrant contradiction to the 1988 Constitution, which considered torture to be a crime not susceptible to amnesty, and with the international treaties signed by the country, including those concerning forced disappearance, the Amnesty Law influenced the institutionalization of human rights in Brazil. This is announced by the very fact that the first National Human Rights Program (PNDH-1), created 
by a commitment made at the World Conference on Human Rights, mentioned nothing about the violence acts committed in the immediate past. ${ }^{10}$ It is important to emphasize that this program was enacted one year after Law 9.140/95, the first reference to the issue in Brazil, making the separation of the themes flagrant.

Although the transition to democracy made it possible to speak of the past in terms of rights and responsibilities, this did not take place initially in the grammar of human rights, but in the political terminology of those who first publicly raised the issue. The efforts to do so preceded the law and came from actors accused by the dictatorship of threats to the national community, with labels such as 'communists,' 'terrorists,' 'enemies of the homeland,' and other associated categories within a negative field of signification projected by the dictatorship. When speaking about their losses, these actors refer to a conflict that had the nation as its object and the paradigmatic antagonism of the Cold War as its theme. The prisons, abrogation of political rights, torture, assassinations, exiles and disappearances perpetrated by the dictatorship would be denounced as instruments mobilized to exclude opponents and to outlaw the political struggle through the use of violence. It was a total war against the "internal enemy" identified as a threat by the National Security Doctrine. This brings us to the third mark conferred to political disappearance. This relates the phenomenon to events surrounding the systematic persecution of a specific, although heterogeneous, social group: the opponents of the regime. This, and only this state violence, would be qualified as political.

This notion of political violence would be projected by those reflections that, from the mid-1970s, focused on the combination of losses suffered by militants who fought the dictatorship, perceived as a defeat in the political field. At this time, the notion was already central for those who were in prison or exile, for the family members of the victims and for the networks of solidarity that supported the militants. Nevertheless, it had more extensive repercussions during the campaign for "Broad, General and Unrestricted Amnesty," which gained strength in $1978 .{ }^{11}$ At that time, the various sectors expelled from politics, ranging from those against whom the repressive apparatus was directed to those who were unable to flourish due to the repression, began to organize. They shared in common the desire for "democratic liberties," including an end to the punishments in vigor and to any new persecutions. Although this had been the focus of the campaign, the social actors involved, militants of social movements and political parties, organized in so-called Brazilian Committees for Amnesty (CBAs), were able to systematize the information provided about the crimes perpetrated during the dictatorship against people in their militant and emotional circles, thereby sustaining, vis-à-vis the national community, their condition as survivors of an unequal conflict in which they were persecuted for political reasons. The notion of resistance is central here. It was amid the debates in this context that the first National Congress for Amnesty would promote the first definition of the political disappeared: militants whose imprisonment, kidnapping or killing were not recognized by the regime (Cabral \& Lapa 1979).

After the amnesty, this movement of denunciations dissipated. While surviving victims and victimizers were incorporated to democracy, and seen to be as equivalent under a common pardon, the dead and disappeared remained as disturbing figures for which the solutions of the transitional period

\footnotetext{
10 It was only in the third version of the plan (PNDH-3), in 2010, that "Memory and Truth" were included in the foci of the program. The creation of a truth commission was proposed, that was realized in the following year. My thesis (Azevedo 2016), discusses the transformations in the form of institutionally dealing with the violence of the past, from the first moment, in which they were ignored, to the current moment, in which a network formed by international institutions, entities, social movements, Brazilian and international, civic and academic entities composed what I call the field of Memory, Truth and Justice.

11 After 1978, a broad set of political actors opposed to the dictatorship joined forces to organize the campaign for Broad, General and Unrestricted Amnesty. It called for the end of the repressive apparatus, the pardoning and release of all political prisoners, and the end of all legal charges and persecution. During the campaign, the first movements were undertaken to investigate and conduct a collective systematization of the violence committed against the political opposition during the military regime. Despite the high popularity of the campaign, the Amnesty Law approved in 1979 by the regime did not include reparations for acts of violence committed and excluded pardons to opponents of the regime convicted for committing "crimes of blood." On the other hand, the law was applied to all agents of the regime, including those responsible for human rights violations.
} 
were inapplicable. Listed and named as a single group in the Brazilian Amnesty Committees, they were taken up as a cause by their own families and by some of the survivors, who began to organize in small groups. Although they were supported by other human rights organizations, they complained of being abandoned by the new social movements and political parties, as well as by a large portion of survivors who adhered to them. ${ }^{12}$ The articulation among these groups can be considered as a form of confronting the collective silence. One of the most notable efforts in this direction was the Brasil Nunca Mais (Brazil, Never Again) project, which provided an important response to the broad set of denunciations made by the Amnesty Committees and also adopted the notion of political violence on which these were based. The family members adopted the same line of approach by organizing themselves nationally to prove that their dead relatives had been murdered, and that the disappeared were in reality dead. Establishing cases for each known name, they would compile the Dossiê Ditadura: Mortos e Desaparecidos Politicos no Brasil (the Dictatorship Dossier: Political Deaths and Disappearances in Brazil). This work was essential for the consolidation of the elements that would define a specific phenomenon, following a dynamic in which the production of a global truth about political disappearance would become increasingly inseparable from the naming of its victims.

Sixteen years after the Amnesty, all of these elements were included in Law № 9.140/95, which declared the disappeared militants to be dead, and considered the disappearance and murder of militants to be political acts, recognizing this condition in the case of 136 people listed by name. It also created the Special Commission on Political Deaths and Disappearances (CEMDP) to evaluate other requests for recognition.

In brief, we can say that political disappearance was recognized as an important issue for the history of the country as it became incorporated into the narratives on politics and political resistance. The demands for the distribution of responsibilities and rights to specific subjects was associated with the production of a memory that located these same subjects among the protagonists of political events of the past. Their memory was consolidated in references taking the form of numbers, narratives, names and images, among other records that appear to both dispel the uncertainties surrounding political disappearance and to attest to the extraordinary nature distinguishing them as a crime against political liberties ${ }^{13}$ Nevertheless, the construction of this more categorical and stable dimension was never separated from the dilemmas raised by the phenomenon as a family drama, which also became determinants for the production of the institutional agendas that developed as a specific social problem.

For people with emotional ties to the disappeared, though, the loss is not necessarily expressed as defeat, but certainly as mourning. It is a complex mourning process in which the association between absence and death - because this death can become suspended in time - results in the perception of an inconclusive death (Catela 2001). If a disappeared political actor, a homogeneous subject defined by law and by the cause, is dead, could a disappeared person be alive? For how long would families emotionally believe in this, even while wishing to prove the opposite? My research has shown me that these are not hypothetical questions, but involve daily moral suffering, which is bitterly nurtured over the years (Azevedo 2016). And while disappearance as a human drama is a source of hurt and suffering for family members, Law 9.140/95 acted only on a small proportion of them, maintaining an abyss between the universe of the state and the universe of families.

\footnotetext{
12 These groups are, for example, the Tortura Nunca Mais of São Paulo, Bahia, Rio and Pernambuco, the Comissão de Familiares de Mortos e Desaparecidos Políticos, and the Movimento Justiça e Direitos Humanos (The Justice and Human Rights Movement). Limited in number, they were supported by Brazilian and international human rights organizations, lawyers, religious agents and academics.

13 Even after the advent of the truth commissions, it continues to be more common for the crimes of the dictatorship to be characterized as crimes against democracy, against democratic freedom, against the left/ progressive forces/ workers/ social movements, rather than as crimes against humanity.
} 
By allowing the death to be officially confirmed through issuance of a certificate, even though recognizing the violence of the state in so doing, the law was designed to restitute the civil rights suspended by a non-documented absence. But it did not prevent families from continuing to await the return of - or from wishing to bury - the bodies, seeking the facts behind each absence, and hoping for justice. In reality, the law increased their responsibilities to prove that the absence conformed to the parameters for recognizing political disappearance. It thus did not prevent its confrontation with new situations in which the death certified by law was placed in doubt, perpetuating the perceptions of absurdity and injustice, a form of treatment that failed to correspond to the human drama or to the political tragedy that disappearance represents, above all when we think of its recurrence and what it shares as a universal phenomenon.

Precisely to shift the phenomena, the international agreements globally supported a definition of forced disappearance that, as we saw above, is based on denial. Disappearance is the denial of destiny, of a body, of facts, of proof, and of identity, which produces "a body separated from a name, a name isolated from its history" (Gatti 2017: 17). It is has been successful as a global category because it allows distinct situations to be dealt with by that which approximates them: the disconcerting character, ambiguity, and the absurdity contained in an act of violence that implies a complete suspension of law. This is how, as a crime and a fact, disappearance is distinguished from killing. In addition to not being seen as the same, the uncertainties surrounding disappearance do not allow any link to either a specific type of violence, or to a pre-defined identity of the victim. In one more contrast with the Brazilian version, forced disappearance is a multiple violation of fundamental rights (to information, psychic and moral integrity, and justice); rights that are simultaneously individual and collective, belonging to victims and to society, and in relation to which extensive state responsibilities are defined. Forced disappearance therefore involves a category that needs to be clarified.

In Brazil where much more specific marks surround the categorical domains, this clarification was established by means of cases. It was through these cases that those people recognized to have suffered political disappearances became distinguished from the Virgílios, following a distinct path.

\section{It's all made up, but nearly all of it happened ${ }^{14}$}

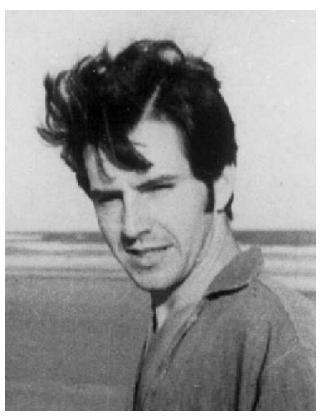

Luiz Eurico Tejera Lisbôa

Born on January 19, 1948, in Porto União, Santa Catarina. Son of Eurico Siqueira Lisbôa and Clélia Tejera Lisbôa. Disappeared on Sept. 2, 1972. Luiz Eurico began his militancy in the student movement. He was a member of the Brazilian Communist Party (PCB), a student activist and also participated in the ALN [Action for National Liberation]. In the student demonstrations of 1967 and 1968, he was arrested a number of times. In 1969, he was condemned to six months in prison in a military police inquest, and began to live clandestinely. After spending time in Cuba, he returned to Brazil in 1971. In 1972, he traveled to São Paulo and the family received no more news about him. From 1978, his wife Suzana Lisbôa, also a militant of the ALN, living clandestinely, began to denounce his disappearance as the probable result of political repression. At this time, she was approached by an acquaintance, who said he had a relationship with the head of the National Information Service (SNI), who reported that Luiz Eurico had married again, and was living in Montevideo, [Uruguay]. Suzana joined the Commission of the Families of the Political Dead and

14 Epigraph of K. Relato de uma busca, by Bernardo Kucinski, about the political disappearance of his sister, Ana Rosa Kucinski. 
Disappeared of the Brazilian Committee for Amnesty. In April 1979, at the Encounter for Amnesty, other family members shared the information that disappeared people may have been buried with false names, possibly those that were used clandestinely in public cemeteries. In the records of the Dom Bosco Cemetery, in São Paulo, Suzana and other family members found the names they were looking for. This included that of Nelson Bueno, buried on September 3, 1972. Nelson Bueno was a name used by the militant while he was in hiding. Informed that his body had been removed from a boarding house after committing suicide, Suzana took a photograph to the location, where she gained a positive identification from the residents. The location of Luiz Eurico was denounced in the National Congress during the vote for the Amnesty Law.

Suzana found the police report on the investigation into the death and filed suit to change the name on the death certificate. At this time, the courts determined exhumation of the body for examination. The analysis revealed that the characteristics of the bones buried in the indicated location failed to match the information in the report that accompanied the cadaver. For this reason, the court also required re-opening the investigation and exhumation of other bodies until they found the corresponding body. The bones returned to the family were shipped to Rio Grande do Sul for burial, in 1982. The re-opened investigation did not bring new elements about the cause of death. But a new version arose, in 1990, when the journalist Caco Barcelos was informed by the cemetery administrator of the existence of a secret common grave, where political prisoners were buried. The movement of families already had this information, but it was the journalist's report that created the public commotion necessary to open the grave. At that time, Barcelos presented a report on the [leading national television news show] Globo Reporter, prompting Suzana to return to the boarding house. While filming interviews for the show, a resident said that Luiz Eurico's room had been invaded in the early morning by two men who killed him, and who told the residents to repeat the version that it had been a suicide. Still in 1990, the movement of family members gained access to the files of the Instituto Médico Legal/SP [São Paulo coroner's office] where it found the request for the examination of the body of Luiz Eurico marked with a letter ' $\mathrm{T}$ ', which was also found in other requests as a reference to 'terrorista.' In 1995, the name of Luiz Eurico was placed in the attachment to Law № 9.140. Suzana became a representative of the movement of families in the CEMDP. More recently, a new analysis of the documentation on the case concluded that the evidence is inconsistent with the version of suicide.

Source: Dossiê Ditadura: Mortos e Desaparecidos Políticos no Brasil 1964-1985.

Like Abílio, therefore, Luiz Eurico is considered a political disappearance. Six years after the trip from which he likewise never returned, his name entered the first list of fatal victims of the dictatorship, prepared by the Commission of Families of the Political Dead and Disappeared of the Brazilian Amnesty Commissions, ${ }^{15}$ even without any additional information about his whereabouts. During the series of searches undertaken by the group, his body was one of the first located and rescued from anonymous burial. As a result, he was included in the main documents that recognize Brazilian political

\footnotetext{
15 Organized within the Brazilian Amnesty Committees, the Commission of Families prepared a first list of fatal victims and began the investigations that led to the location of documents and some bodies, and also mounted the first cases. With the conclusion of the Amnesty Committees, the Commission of Families became an independent organization. In 1993, the Institute for Studies about State Violence (IEVE) was created, and organized an archive of the documents related to the searches and published in the Dossiê Ditadura, since the latter's first issue in 1984. It served as a basis for the preparation of the list in Attachment I of Law № 9.140/95, and for the cases, which were presented in greater detail to the Special Commission on Political Deaths and Disappearances. The production of the requests was an important moment in the articulation of the movement of families and of the expansion of the cases. In 2007, they were published in the report of the Special Commission (Brasil 2007). The advances were updated in the Dossiê, leading to the third edition in 2009.
} 
disappearances: the Dossiê Ditadura (Dictatorship Dossier); the annex to Law № 9.140/95; the final report of the Special Commission on Political Deaths and Disappearances (CEMDP); and more recently the report of the National Truth Commission. ${ }^{16}$

Comparing the disappearances of Luiz Eurico and Abilio with that of Virgílio, we find as a notable difference the existence of an organized report for the first two. Known as cases, these reports result from the communications made by family members in the forums for recognition. While the family members of Luiz Eurico communicated his absence to the first forum created by the social movements (the Brazilian Amnesty Commissions), Abilio's family only did so in the institutional spaces established in the 199os. Despite this fact, many similarities can be observed between the two reports. The most evident is their capacity to raise opportunities for understanding and communicability about the unusual reality that they revealed.

In the universe of recognition in which they operate, the cases are a narrative form. The means through which the disruptive and exceptional events - incommunicable in their pain and enigmatic in their developments - are associated with a form of understanding them as the expression of a broader phenomenon. Once formulated, each case becomes a narrative of reference, of unique and irreducible content, revised, and at times corrected, but regularly repeated over the years. It is distinguished by a name, a photograph, brief biographical data, followed by a narrative divided into two organizational elements: the affirmation of a militant trajectory and the reconstitution of state violence. They are associated in a script that presents the sequence of events behind the events, attempting to answer why, when, where and how they took place. When this is impossible, it indicates the possibilities suggested by the searches and information obtained. This information is based on a wide variety of artifacts that constitute proof, which may include photos, inquests, investigative reports, testimony, documents from security agencies under the dictatorship, journalistic investigations and books. The case is thus born as a product of searches, proofs and information organized in a coherent and verisimilar narrative that links a particular absence to the phenomenon of political disappearance.

The aim of the cases is to mitigate the incomprehensible aspects of each absence by attributing a precise meaning to it. In the case of Luiz Eurico, we have seen that this movement was enabled by a narrative in which the chronological ordering of the discoveries made by Suzana Lisboa, his wife, could not fully reconstruct the events that led to his death, insofar as they remained uncertain amid the plurality of existing versions, yet the process was able to reveal events and bureaucratic records that allowed his mysterious vanishing to be confirmed as a political disappearance. The narrative articulates a hypothesis about the impossibility of reaching a definitive conclusion concerning what took place, dispelling the enigmatic perspective that usually accompanies cases of disappearance (Ferreira 2011). Thus his absence is interpreted as a decipherable event within a restricted framework of possibilities. Moreover, while in terms of the concreteness of the events, some stories, like Luiz Eurico's, contain details that appear absurd, others lack information that allow any outcome to be presumed, as in the case of Abilio. As a form applied without distinction, the cases are a safe narrative located between the singularity (and the uncertainties) of an event with an individual and a single destination (prison, torture, death and hiding of the body) safely attributed to a collective subject.

\footnotetext{
16 The complete cases can be found in the cited reports (Almeida 2009, Brasil 2007, CNV, 2014). A review reveals their similarity, even in visual terms. The three publications present the universe of the dead and disappeared that they recognize in the cases. They share a narrative form, the same compositional elements, use the same data and documents, and reach the same conclusions. The difference resides in the number of cases, recognized by each one. There are 357 for the Special Commission, 436 for the movement of families, and 434 for National Truth Commission.
} 
It is not by chance that the affirmation of the victim's political trajectory is the first point of this narrative. In the case of Luiz Eurico, the lack of communication on the part of the person who traveled is not, we can imagine, uncommon. Even with the passage of years, there is nothing that allows us to suppose a necessarily tragic (or political) motivation behind the failure to return or communicate. In principle, therefore, his disappearance is inserted in a broad range of possibilities that make it difficult to reach conclusions. This gives room to those who claim that he is living in another country. It was not so much the time passed, but Suzana's knowledge about her husband's political activities, as well as her involvement in the same networks of militants and underground life, that allowed her to see the absence as a break from routine. Recognized as a militant because of his trajectory in the student movement, and a member of an organization that struggled against the dictatorship, Luiz Eurico's fate is associated with a situation that in 1972 was already perceived as a risk among those activists engaged in the resistance. For this reason his name entered the first list of the disappeared.

The second point is the demonstration of the existence of state violence, which involves not only the participation of some institutions in the production of events, but also the indifference of others to the attempts to reveal them. At the beginning of the process, the communication of the case in the networks of solidarity and defense of the persecuted was the logical counterpart of dismissing the possibility of going to the police to report the disappearance of someone missing. The lack of admission of possible imprisonment also weakened the legal defense measures. ${ }^{17}$ With the political opening towards the end of the dictatorship, the search followed a routine in which the confrontation with the institutions - the cemetery, funeral service, coroner's office (IML), police, courts, and the Special Commission on Political Deaths and Disappearances - would lead to registers that produced a status of truth for what had been previously been uncertainty. All of these institutions are accused of posing obstacles to obtaining the truth, however, either by registering facts considered to be false, such as the obituary issued in the name of Nelson Bueno and the police investigation that classified his death as suicide (the so-called 'versions' of the dictatorship); or by ignoring or having no intention of discovering the true facts; or through the action of the courts, which altered the obituary maintaining a questionable causa mortis; or by the attribution of a political status to the death by the Special Commission on Political Deaths and Disappearances, which drew no distinction between suicide in response to the threat of imprisonment and homicide.

If all of these registers kept Suzana in a state of doubt, they were also converted into proofs that allowed the recomposition of details that untangled Luiz Eurico's fate from the very wide range of possibilities in which it had initially been inserted. It is in this sense that the case establishes a secure path between an absence about which many doubts still remain and the confirmation of political disappearance. But this recomposition is also a repository of dissatisfaction. By using ambiguities as part of the script, the case confronts the institutions, blaming them for the continuing uncertainties, for the unattainment of desires for truth and justice, and for the insufficiencies and the injustices committed. The impossibility of affirming precisely what took place does not make it impossible, however, to mount a case of political disappearance. In reality, questionings and uncertainties are also constitutive of political disappearances, resulting in a story that seeks to denounce the lack of care.

Considered individually, the death of Luís Eurico continues to evoke a series of uncertainties, whether because of a lack or an over-abundance of information: was his body really buried as Nelson Bueno? Was the body given to the family - which was never identified and whose discovered in the cemetery was based on the description of an inquest deemed to be forged - really his? Was he killed or did he kill himself to

17 Despite this fact, many family members began their search by filing a habeas corpus and/or seeking information from the police, the armed forces, the courts and Brazilian or international civil and military authorities in general, both individually and collectively, officially and extra-officially, with results that varied between information not found and official information that someone is 'at large.' 
avoid being jailed? If he was killed, by whom and how? Clearly any removal of doubt is necessarily relative. On one hand, the production of a narrative that unites the known fragments must offer a single and true version. To do so, the association with other cases is essential, both to fill in the gaps and to qualify the uncertainties, and to relieve the disbelief generated by the history being proposed. Yet on the other hand, we can observe that fragmentation and doubt are not eliminated, but instead fed by the demands for truth and the accusations against the institutions that have shirked their responsibility to establish it. Without removing doubts, the case circulates among them, or turns them into a demand, incorporating them into the narrative form on which order and meaning are produced.

As a consequence, it is no longer sufficient to say that the cases are narrative forms only. More than this, they introduce discursive practices and forms of knowledge. They are products of the relationship between family members and institutions, as well as artifacts around which were organized a political agenda and a cause in which various social actors were involved. Their existence signifies that a process of revelation was initiated, based on which a second protagonist arises. In the case of Luiz Eurico, we see Suzana stand out, not only as his widow, but as someone who demands recognition, initiating the series of contacts with institutions that certify truths capable of triggering nothing more than concern and questioning. Her search makes her a participant in the initiatives of a collective. It was as a militant of the Commission of Families of the Political Dead and Disappeared and a representative of the movement of families in the Special Commission on Political Deaths and Disappearances that she - and the collective to which she belongs - were considered in the report as protagonists of the investigations that provided some answers to their questions. This could only take place amid the construction of relations, whether between Suzana and other families, or between the events that happened to Luiz Eurico and those that happened to other disappeared militants. Both the rise of the hypothesis of the burial with a false name, as well as the localization of the body, and even the mistrust in relation to the version of suicide, could not be separated from the process of collectively revealing the methods used by the dictatorship to kill and dispose of the bodies of their opponents and/or camouflage these murders. Because of the location of his body, therefore, the particular case of Luiz Eurico, provides empirical elements that prove the more general theses about these methods. This movement of constant comings and goings between the particular and the collective is also characteristic of the routine of the cases.

Developing their activism in relation to the institutions to which they turned with a certain amount of distrust, the family members found the cases to be a useful mechanism to generate order and meaning and to collectivize their personal dramas. Through them, they became subjects of knowledge, producing knowledge shared in the process of conversion of their personal pilgrimage into collective action, an essential part of the organized action that led to recognition of the movement as a collective political actor. In the public arenas dedicated to the theme, the term familiar does not refer only to the kinship relations, but to a structural position within the social field that they return to debate, investigate and restore the violence of the dictatorship - in which the family is seen as a subject of rights produced less by the disappearance per se than by the search. 


\section{Militant vulnerability}

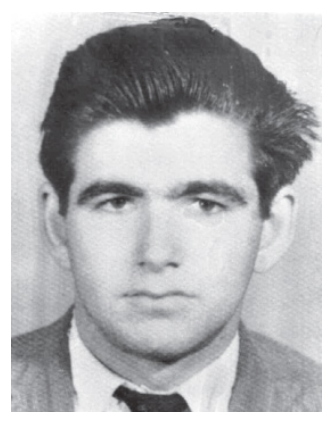

Denis Casemiro

Born in Votuporanga, in the interior of São Paulo state, on December 9, 1942. Son of Antônio Casemiro and Maria Casemiro. In his native city he was a construction worker and farmhand. He participated in the Votuporanga Farmworkers Union. In 1967, he went to São Bernardo do Campo to work at Volkswagen. At this time he met Devanir José de Carvalho, who was also assassinated by the repressive apparatus, and Devanir's brothers Jairo and Daniel. The latter is on the list of political disappearances. Denis began to participate in the opposition to the dictatorship when he joined the Ala Vermelha [The Red Flank] and later the Vanguarda Popular Revolucionária [Popular Revolutionary Vanguard] (VPR). He moved to Southern Pará where he began to care for a small farm close to Imperatriz, in Maranhão state. From there he considered undertaking political and military action in the rural region.

In April 1971, he was found and arrested by police officer Sérgio Paranhos Fleury, who took him to the DOPS/SP, where he was tortured for nearly a month and then killed. During this incarceration he was always moved through the corridors of the police agency with a hood covering his face to make it impossible for other prisoners to identify him. One of these prisoners, Waldemar Andreu, who came from the same region as Denis, had spoken with him for a few minutes. He was sure that the removal of the hood was a sign that the torture was over and that the danger of assassination had passed. However, Denis was shot on May 18, 1971 by officer Fleury. In a report found in the DOPS archives there is a version by the officer, according to which Denis had tried to escape during a stop on the road, when he was being taken from Rio de Janeiro, where he was taken for questioning by the police, and then back to São Paulo. After rolling down a river bank the police officer had to shoot him and was arrested once again nine hours later. Taken by the officer to the hospital, he later died from his wounds. The request for an autopsy made to the coroner confirmed the police version without any mention of the state of the body, although it described wounds to his hand, which indicated a gesture of defense. Denis was buried by the state as an indigent person, and his data were altered to make identification impossible. No official communication was made about his death. In the registration book at the cemetery, he was identified as 40 , when in reality he was 28. The clarification of his arrest, torture and death began in 1979, during the Amnesty campaign, with the discovery of the register of his death by the Commission of Families of the Political Dead and Disappeared. His remains had been deposited in the secret grave at the Dom Bosco Cemetery, in the neighborhood of Perus, in São Paulo (SP). The identification was only possible because Mayor Luiza Erundina called for an investigation into the grave, which was opened in September 1990. In 1991, Denis was identified by Unicamp among the bodies in the grave and taken to the city of his birth. His name is found in the list of political disappearances in attachment 1, of Law 9.140/95.

Source: Dossiê Ditadura: Mortos e Desaparecidos Politicos no Brasil 1964-1985.

Denis Casemiro disappeared after being seen under arrest at the Department of Political and Social Order (DOPS) of São Paulo by other militants, although his imprisonment and death were never officially confirmed. Considered a political disappearance ever since, his name was found in the registration books of the Perus Cemetery. In an effort to prove that crimes had been committed against him, the investigations located classified documents that registered his imprisonment, including a report about his death, attributing it to an attempted escape. Considered a fallacy to cover up his execution, 
the version is contrasted with other discovered documents, such as the autopsy and the cemetery registration book, which include adulterated information, despite the correct name, indicating an attempt to conceal the body. ${ }^{18}$

Consolidated in the Dossie and in the report by the Special Commission on Deaths and Disappearances, the case was recently presented at a hearing of the Rubens Paiva Truth Commission (CVRP) of the São Paulo State Legislature. ${ }^{19}$ The case includes an unexpected line of inquiry suggested by one of the witnesses. Denis's childhood friend, Waldemar Andreu, said he believed that the arrest was an act of revenge by the police officer involved against Denis's brother, who had also disappeared, since Denis had abandoned militant activities by the time he was killed. Andreu also rejected the idea that Denis had been tortured for one month, because "he walked normally," suggesting that he had not been subject to violence.

Coordinating the hearing were two aides to the Rubens Paiva Truth Commission who were also militants in the Commission of Families: Ivan Seixas and Amelinha Teles. Both were involved in the production of the Denis Casemiro case, from the location of his name in the cemetery to the investigations produced by the Parliamentary Investigation Commission created in 1990 by the São Paulo City Council to investigate the secret grave discovered in the Perus Cemetery, to which they had also been aides. Provoked to speak, Ivan began his testimony by arguing that the statements by Denis's old friend Andreu were his own opinion. In Ivan's words, although this was "an impression that he [Andreu] has," it failed to match what had been found. Ivan had documents in his possession, which he analyzed based on his knowledge about the operations of the left and the state's repressive forces. This analysis indicated limitations to Andreu's assertion, which Ivan attributed to the fact that they were based on nothing more than Andreu's own experience. Although Ivan had also mentioned his personal proximity to the militant, in order to reaffirm the case he turned to the statement given by Denis at the Department of Political and Social Order (DOPS) of São Paulo. This document registered his militancy and his direct contacts with the national command of his political organization at the time of his arrest.

If this information was known to the repressive forces and was admitted by Denis at DOPS, it might be 'supposed' that he was tortured to reveal it and that the story that he had "rolled down a river bank" had been invented to explain the marks of violence. Although there were no witnesses or other artifacts to prove torture, Ivan believed it could be presumed because this was the interrogation method used by the dictatorship on political prisoners. It could also be supposed that Denis was killed because he refused to cooperate, since this solution "was common procedure at the time." But not only death was inscribed in a method. As Amelinha proceeded to indicate, after death, an entire institutional mechanism was triggered to hide his body, making it difficult to prove the murder. The hiding of the body and the alteration of data on the death certificate were evidence that his tragic destiny conformed still to routine forms of political disappearance.

Once again, in the eyes of the movement of families, the doubts and the consequent need to work with suppositions fail to undermine the veracity of the narrative, or make its conclusions a mere matter of opinion. To the degree to which they are based on what can be described as a repressive methodology, identified with the action of the police and military forces who tortured and killed, investigators who covered up these actions, and funeral agents who legalized the disappearance of bodies, these suppositions have become inscribed in the political and military antagonisms existing between the opposition and the dictatorship. Hence, they are grasped more as probabilities than as suppositions - that is, as affirmations

18 Documents located at the time of the opening of the archives of the Department of Political and Social Order of São Paulo (DOPS/SP) in 1991.

19 A commission that collaborated with the National Truth Commission, created to conduct investigations into the crimes that took place in São Paulo, which victimized people born in the state, and that were perpetrated by state government agents. The facts presented below took place at the $7^{\text {th }}$ Public Hearing of the CVRP, on February 21, 2013. 
situated in the field of statements of opinion, based on particular experiences inseparable from the perspective of those who make the statements, rather than statements of knowledge, deemed to be objective because they are based on categorical propositions, whose general and verifiable validity is equivalent to the knowledge amassed by specialists (Boltanski 2000).

The discovery of the repressive routine was itself an outcome of the establishment of a routine by the family members during their visits to cemeteries, IMLs and archives, their seeking of responses from the institutions, and even the actions within them. The command of both routines - the repression and the investigation - allows the members of the movement of families to declare themselves to be the ones with knowledge, responsible for the construction of a case without which the dead and the disappeared have neither body nor history. The authority of their speech was already forged in their searching and in the knowledge accumulated through it, by the affirmation of this search as a struggle provoked by their suffering and against the denial and silencing. For this reason, it is interpreted as resistance, similar to the kind engaged in by those who disappeared. The unveiling of violence as a routine inscribed in the fate of militants during the dictatorship results from the search routine, which is itself violent, turning the family members into militants. A process of simultaneous inclusion of the disappeared and their families in political communities formed by actors who are characterized as being simultaneously victims and militants. Interpreted as resistance, political militancy is closely connected to the notions of struggle and vulnerability, establishing a symmetrical relationship between the disappeared and their families. ${ }^{20}$

By closing the political and mnemonic marks of political disappearance around an identity perspective, militancy relates it, as a legal framework, to the recognition of particular rights. In this way, it not only serves to control the uncertainties present in different ways in the cases, but ultimately defines whether a specific disappearance is political or not, as we can note if we return to the case of Abilio Clemente Filho. His story is the most wrapped in mystery, given that there is no information that is effectively relevant beyond his own disappearance. His death was not announced in the newspapers, as occurred with some of the disappeared, his body was not found and there are no documents from the "repression" about his case, as in the cases of Luiz Eurico and Denis. In 43 years, nothing more than extremely fragile clues have been learned about Abilio's fate after his trip to Santos. The family undertook searches, requesting help from Antônio Mentor, a former colleague of Abílio and a state deputy at the time. According to his statement at the public hearing on the case held by the Rubens Paiva Truth Commission, the initial possibility was that he may have been the victim of a drowning. They searched at the coroner's office, the fire department, hospital and police without success. ${ }^{21}$ They came to consider the possibility of an act of repression "of the kind occurring at the time.” They then took the search to locations such as DOPS and DOI-CODI, but did not gain any information.

Although limited, the information shared by Antônio Mentor at the hearing, which was all related to the proof of Abilio's militancy, acquired central importance for the disappearance to become a case, something also contextualized by the testimony of Amelinha. She began her statement saying that she did not know Abilio but knew about the case of Abílio Clemente Filho, in 1990, at the time of the opening of the mass grave at the Perus Cemetery. Generating a strong media impact, the opening of the grave publicly exposed images of skeletons, revealing the political dead, disappeared and their families to a national and international audience. In this context, the trio formed by Amelinha, Ivan and Suzana was particularly exposed because they actively participated in the CPI as aides. This involvement would contrast with the

20 Similar to the kinds observed by Vianna (2014) and Efrem Filho (2013) for other ethnographic contexts.

$218^{\text {th }}$ Public Hearing of the CVRP, February 25, 2013. 
distancing of Abilio's family from these spheres of recognition. Something that would only be overcome with the public release of the work of the Commission of Families in this context, when Amelinha was sought by Abílio's sister.

Amelinha's alleged surprise over Abilio's case is no different from my own surprise at the Ricardo de Albuquerque Cemetery. Something that, as I affirmed, denotes a perception of political disappearance as a reality well grasped by the social network constituted around this task. Thus she was surprised by the fact that this network - "we who came from the struggle of the CBAs [Brazilian Committees for Amnesty]" - did not know about the episode. The surprise also reflects the certainty that the authority of her speech is based on the knowledge accumulated by the movement of families about the Brazilian state's repression and its victims - specific and general knowledge that when associated seeks to take precedence even over the knowledge a witness can provide, as we saw in the previous case.

Amelinha simultaneously demonstrated knowledge that many people are looking for disappeared persons in Brazil. She also said that many of them turned to the Commission of Families for help at the time of the opening of the mass grave. Nevertheless, she discarded the possibility that they could help with those cases perceived as 'non-political,' despite the range of different cases that fit this classification. Observing the existence of different types of disappearance, the Commission of Families differentiated the political cases from a more general and heterogeneous range of cases, dedicating itself only to the former. Even though, in this process, the other cases were not specifically stated to be irrelevant, the Commission understood that they comprised another phenomenon and another problem outside both the scope of its struggle for recognition and the scope of the institutions with the power to officially classify them. This differentiation thus created a hierarchy of the different types, insofar as some come to be considered the outcome of a violent act eligible for indemnification and recognition, while others remain in the broad field of ambiguous events that do not constitute objects of public interest or reparation.

The Abilio case - particularly when we consider the history of Virgílio as a counterpoint - shows that the borders between these types of disappearance are not so clear in the empirical situations as they are in categorical terms. In both cases, we have people with an alleged history of political militancy who disappeared in unknown circumstances and never returned or sent news to their relatives. Nevertheless, only one of them came to be recognized. The non-recognition of Virgilio first involves the fact that his family was unable to gain access to the social actors and institutions that can provide this recognition. Amelinha's narrative about how Abilio nearly remained in this zone of non-recognition shows how the families believe that they are the first, if not the most important, of these actors. The Abilio case is the only one of those addressed here that was not directly recognized by Law № 9.140. His name is not in the attachments, and is not present in the Dossiê. According to Amelinha's explanation, without "political activity" Abilio's family were unable to obtain the support needed to bring their particular charges to the cause, and the political organization to which Abilio was connected also failed to do the same. As a result, Abilio remained "disappeared on the left" - that is, he remained unknown by the support group dedicated to the task of defining political disappearance and naming its victims. Sought by Abilio's sister, Amelinha used the same methods and research routines to find proof, but did not know if she could accept him as a case. She verified with Antonio Mentor, a recognized militant, that Abilio was an active member of the left. His case was then recognized as a political disappearance, even without more details that could prove or discount the involvement of the dictatorship.

In this regard, something implicit can be observed in all the cases: the condition for a denunciation to be admissible is the victim's political activism. Once proven, the case is assumed and the political disappearance considered a probability. As can be seen in the conclusions presented by the rapporteur in the Abilio case to the Special Commission on Deaths and Disappearances, this understanding is not limited 
to the movement but is shared by the institutions too. While in the former cases, political disappearance is defined by associating elements relating to the nature of the victim and the violence involved, the Abilio case reveals, as an exception, the norm by which the nature of the victim defines the existence of violence and its nature.

\section{Final considerations: back to Virgílio}

In the course of this article, I have argued that the most general phenomenon of disappearance, its definition as absence, is related to a high degree of uncertainty and ambiguity. The dissociation between name, body and history provokes "an ontological problem, which is also methodological, and even ethical and theoretical" (Gatti 2017: 29). These are exceptional and disturbing phenomena that nevertheless, when they occur, give way to new routines and processes of normatization. As Gatti argues, the very constitution of the disappeared as an object of transnational humanitarian concerns forms part of a movement born from the devastation generated by disappearance as a state policy in Argentina, the original location of the invention of the disappeared as a legal concept, enabling the emergence of a process of legal translation that transformed it from a phenomenon to be explained into a variable that explains. This is because the category has allowed the naming, in different local contexts, of that which has no name, initiating a process that, for Gatti, involves the increasingly creative expansion of its use.

In Brazil, this process of configuration took place synchronically, but in parallel both to the construction of the paradigm of forced disappearance in Argentina, a country with which Brazil shares the geopolitical and ideological context of the occurrence of disappearance, as well as the transnationalization of the category. However, this does not take into account the fact that the institutionalization of political disappearance in Brazil took place only one year after the country signed the Inter-American Convention on the Forced Disappearance of Persons, adopted at a session of the General Assembly of the OAS, held in the country in 1994. It is noteworthy that the convention was ratified by Brazil only in 2014. The international convention of 2007 was ratified three years later. Nevertheless, the crime of forced disappearance was still not subject to domestic jurisdiction, as required by these adhesions, allowing a broad range of cases of violence to continue to be poorly supported in legal terms, given that the category of political disappearance is only attributed to events that took place during the dictatorship. This temporal marking is just one of those on which the category finds very specific local configurations, which, based on the political and institutional routines that produce them, seek to dispel the uncertainty and ambiguities that characterize forced disappearance as a universal phenomenon and a transnational category.

It was through the denunciations, materialized in the cases, that the movement of families was able to break some of the layers of silence demanded by the complex Amnesty process. They insisted on showing that the political events of the time had affected and set new paths to the lives of social subjects beyond simply imposing political and social order on the country. Moreover, by interlinking these two dimensions, they wanted to show that institutional violence - in its capacity to disrupt personal trajectories - was the most relevant political event of the period. By speaking publicly of their pain, they initiated and sustained an important movement of critical reflection about how we deal with past violence, but without considering the entire universe of losses. As an institutional response to their demands, a dynamic of recognizing particular rights was established, but only for those victims recognized by the movement of families, based on an identity-based approach. Consequently, political disappearance continued to be marked by a particularized definition that previously excluded those excluded from this identity (Sarti 2011). ${ }^{22}$ This exclusive association of systematic

22 It is important to note that although the militant identity does not imply, a priori, a profiling based on class, race, gender or generation, it produces exclusions based on all these markers as a result of the social profile of the political organizations, parties and social movements that acted during the period. 
state violence with militants expanded the possibilities of recognition for its members, preventing the possibility that a probable victim not be recognized due to the effectiveness of the cover-up methods. However, if we recall Virgilio and the secret grave containing two thousand disappeared people, only 14 of whom are considered political, it is clear that this becomes a barrier to recognizing other victims of forced disappearance.

Reflecting on the activism of the families of victims of institutional violence in Rio de Janeiro, particularly police violence, Vianna (2014) argues that their strategies for making denunciations are developed in a "dynamic process of producing tensions around the pairing of the nature of victims and the nature of violence" (Vianna 2014: 218). Part of a struggle for visibility, this dynamic seeks to mark a specific type of violence organized not only in relation to the state as the producing agent, but also in relation to the antagonistic nature of this relationship. The rhetoric of these movements reveals that the political transition was incapable of abandoning the framing of social conflicts as a security issue. The "problem of public security," which substituted "national security," mobilizes state apparatuses and social anxieties, based on the exclusion of an entire peripheral population in the large cities, which is conceived as an enemy against whom violence is justified or legitimated.

There is a specific type of violence inscribed in the fate of the favela resident, therefore, due both to the nature of the state action and also the nature of the victims, circumscribed by a territoriality associated with aspects of class and race, making them potentially vulnerable subjects (Vianna op. cit.). As we saw, a similar logic oriented the delimitation of the universe of the victims of the dictatorship. The common symbolic repertoire implies similar forms of perceiving the vulnerability of an identity group in relation to the state, despite contextual differences. The transformation of risk into routine is the result of the location of these groups at the margin, where they are simultaneously considered as both a threat and as unimportant. This marginal place where favela residents are now situated by the drug war is symmetrically equal to the place occupied by militants during the war against communism. And it is quite common to hear movements of family members linked to the two processes establish a relationship of continuity by substitution.

At the event held in the Ricardo de Albuquerque Cemetery, on occasion when both communities of victims strove to make these correspondences, my attention was drawn to the resentment expressed by victims of the democratic state towards something that, nonetheless, is not symmetrical. Although both kinds of deaths are the outcome of mechanisms used in the combat against a social group defined as an enemy, thus constituting political violence, how can we explain the fact that some losses are considered routine and banal, while others involve politics? This is a crucial problem for a movement that also intends to discuss deaths and lives that are important in a struggle that is not only for rights, but for the right to have rights (Arendt 2000), as Sanjurjo and Feltran (2015) astutely point out. As the latter authors argue, this process involves succeeding in becoming part of a national political community from which these subjects are excluded. Nevertheless, Vírgilio and the common graves compel us to seriously question whether all those treated as a threat by the dictatorship were able to regain a sense of belonging to this community.

Recently, the National Truth Commission defined the dictatorship as a system in which violence became the general norm for resolving social conflicts and administrating the life of the country's populations. If so, it is necessary to accept that a large variety of social subjects suffered from violence, whether they declared themselves opposed to the regime or not. This is because the struggle against the domestic enemy took place in society as a whole, where it would be submersed and disseminated. The accusation

This can be observed in the social profile of the recognized political dead and disappearances, although no deeper study exists on this aspect. The Project Brasil Nunca Mais (Brazil Never Again) presented a more general "profile of those involved," since it referred to people processed by the regime. This profile was male (88\%), young (38.9\% were 25 or younger), urban (although most were migrants from the interior) and university educated (more than half). There are many students and workers, as illustrated well by the cases chosen for this analysis. 
of subversion, which was sufficient, could be made against each and every subject in a more or less fluid manner. As an ideological divide, it was combined with other categories of segregation in a variety of ways, which, in a diverse and unequal society such as Brazil's, separated (and still separate) the subjects who belong from the others who threaten. Despite this fact, the National Truth Commission conducted an anonymous recognition of these other acts of violence, and characterized as political only those closely connected to militant activism, naming and even accounting for its victims only. The commission thus reaffirmed the narratives that focus on the antagonism between the dictatorship and the resistance, a point of convergence for those memories that sought national projection and for an expressive part of the historiography dedicated to the period. This movement leaves submerged other memories and homogenizes views concerning what political experiences mattered most under the dictatorship. The distinction of state violence into political and common appears to result from a failure to recognize the losses and grieving of subjects who continue to be marginalized, and for this reason who are not accepted as actors in national politics.

These are vulnerabilities of long duration, based on long-lasting inequalities and prejudices, many of which can be traced back to an origin in more remote times. Not for this reason, though, did they fail to be reflected in a configuration of violence specific to the moment and related to the political projects of the military regime. These included indigenous peoples, targets of pacification policies and tutelage, who had experiences of terror and disappearances, as did peasants and other rural populations considered threats to private interests and to projects of economic expansion and national integration. It also includes populations living in favelas, who are targets of forced evictions, heavy policing and persecution of their forms of political, social and cultural organization, who are classified, along with the most traditional workers, among the dangerous classes (Leite 2012) and who have also endured instances of unrecognized murders and disappearances. Other groups, because of a way of life that conflicted with the morality promulgated by the regime, similarly underwent processes of criminalization that were related less to their recognition as political actors than to their association with urban marginality and criminality. These sectors, considered to be 'common' criminals and offenders, suffered from extremely cruel forms of combat, which even trained combatants and provided expertise subsequently used to violently suppress political organizations, as well as assist their political repression. ${ }^{23}$ For the poor and the marginal, the principal victims of death squads, the dictatorship had already inflicted torture, imprisonment and mass graves of disappearance. In this situation, the politicization of a certain violence has, as an implicit counterpart, the discrimination of a limit beyond which lives cease to be politically relevant (Agamben 2007). Perhaps it is on the margins of these other collective experiences of state violence that we can find one of the factors constructing what we take to be our lack of memory. As seemed to me the case with Virgilio's cousin, it may be that for some social sectors, it is not derived from forgetting as such, but from a sense of alterity, which leaves social subjects unable to relate the hegemonic memories to their own experiences of violence during the period and/or to recognize their experiences as fitting into those narratives. Considering the marks by which we understand political disappearance in Brazil, I believe it is important for us to begin to take seriously the hypothesis that our profound social inequality has an underappreciated role in our forgetting.

23 The 'death squads,' extermination groups formed by police officers, arose accompanied by a discourse of defending society against 'bandits,' under the slogan that the only good bandit is a dead bandit. The squads were born from the involvement of top-ranking police in the criminal economy of cities like Rio de Janeiro and São Paulo, above all in the networks of illegalities surrounding drug trafficking and prostitution (Teixeira 2012). The violent practices of these groups were employed in political repression, which incorporated their techniques and some of their members. It is important to remember that when actions from the repertoire of resistance, such as bank robberies, were framed within the National Security Law, the latter indiscriminately punished all those responsible for committing them. Nevertheless, 'common' criminals were not accepted as equals, either by the 'political actors' or by the dictatorship, which at the beginning of political repression reformulated the National Security Law to prevent them from receiving benefits granted to the political actors (Faria 2005). Through their coexistence in the prisons, the political prisoners learnt about the systematic violence perpetrated against the incarcerated population through the incursions of death squads to torture them, and often kidnap them, never to be seen again. Their names, however, remain unknown. 
Received: July 10, 2017

Approved: November 13, 2017

Translation: Jeffrey Hoff

Revision: David Rodgers

\section{References}

ALMEIDA, Criméia et al. 2009. Dossiê Ditadura: mortos e desaparecidos políticos no Brasil (1964-1985). São Paulo: Imprensa Oficial.

AGAMBEN, Giorgio. 2007. Homo Sacer. O poder soberano e a vida nua I. Belo Horizonte: Editora UFMG.

ARAÚJO, Fábio Alves. 2012. Das consequências da "arte" macabra de fazer desaparecer corpos: violência, sofrimento e política entre familiares de vítimas de desaparecimento forçado. Tese de doutorado. Instituto de Filosofia e Ciências Sociais, UFRJ.

ARENDT, Hannah. 200o. Origens do Totalitarismo: anti-semitismo, imperialismo, totalitarismo. São Paulo: Companhia das Letras.

AZEVEDO, Desirée. 2016. "A única luta que se perde é aquela que se abandona." Etnografia entre familiares de mortos e desaparecidos políticos. Tese de doutorado. Instituto de Filosofia e Ciências Humanas, Unicamp.

BOLTANSKI, Luc. 2000. El amor e la justicia como competências. Buenos Aires: Amorrortu Editores.

BOURDIEU, Pierre. 2011. Razões práticas: sobre a teoria da ação. Campinas: Papirus.

BRASIL. 2007. Direito à verdade e à memória. Brasília: Comissão Especial sobre Mortos e Desaparecidos Políticos.

CABRAL, Reinaldo; LAPA, Ronaldo. 1979. Desaparecidos políticos: prisões, sequestros, assassinatos. Rio de Janeiro: CBA RJ/Edições Opção.

CANDAU, Joël. 2011. Memória e Identidade. São Paulo: Contexto.

CATELA, Ludmila. 2001. Situação-limite e memória: a reconstrução do mundo dos familiares de desaparecidos da Argentina. São Paulo: Hucitec/ANPOCS.

COMISSÃO NACIONAL DA VERDADE. 2014. Relatório, Volume I. Brasília: CNV.

DAS, Veena. 1995. Critical events. An antropology perspective on contemporany India. New Delhi: Oxford University Press.

EFREM FILHO, Roberto. 2013. “Corpos Brutalizados: conflitos e materialização das mortes de LGBT.” Anais do $37^{\circ}$ Encontro Anual da ANPOCS. Águas de Lindóia. Mimeo.

FARIA, Cátia. 2005. Revolucionários, bandidos e marginais. Presos políticos e comuns sob a Ditadura Militar. Dissertação de Mestrado. Instituto de Ciências Humanas e Filosofia, UFF.

FERREIRA, Letícia. 2011. Uma Etnografia para Muitas Ausências: O Desaparecimento de Pessoas como Ocorrência Policial e Problema Social. Tese de doutorado. UFRJ/Museu Nacional/PPGAS. . 2007. Dos autos da cova rosa. A identificação de corpos não identificados no Instituto Médico Legal, 1942 a 1960. Dissertação de mestrado. UFRJ/Museu Nacional/PPGAS.

. 2013. "Apenas preencher papel: reflexões sobre registros policiais de desaparecimento de pessoa e outros documentos." Mana. Estudos de Antropologia Social, 19(1): 39-68.

FOUCAULT, Michel. 2007. "Verdade e Poder." In: Microfísica do Poder. Translated by R. Machado 23a. ed. Rio de Janeiro: Edições Graal. pp 4-12.

GATTI, Gabriel (ed.). 2017. “Prolegómeno. Para un concepto científico de desaparicón”. In: Desapariciones. Usos locales, circulaciones globales. Bogotá: Siglo del Hombre Editores. pp 13-32.

HOBSBAWM, Eric. 1994. Era dos extremos. O breve século XX. São Paulo: Cia da Letras. 
LEITE, Márcia. 2012. “Da 'metáfora da guerra' ao projeto de 'pacificação': favelas e políticas de segurança pública no Rio de Janeiro". Revista Brasileira de Segurança Pública, 6(2): 374-388.

SANJURJO, Liliana; FELTRAN, Gabriel. 2015. "Sobre lutos e lutas. Violência de Estado, humanidade e morte em dois contextos etnográficos." Ciência e Cultura, 67(2): 40-45.

SARTI, Cynthia. 2011. "A vítima como figura contemporânea." Caderno CRH, 24(61): 51-61.

TAUSSIG, Michael. 1995. "Culture of Terror-Space of Death: Roger Casement's Putumayo Report and the Explanation of Torture". In: Nicholas Dirks (ed.), Colonialism and Culture. Ann Arbor: The University of Michigan Press. pp. 135-174.

TEIXEIRA, Alessandra. 2012. Construir a delinquência, articular a criminalidade. Um estudo sobre a gestão dos ilegalismos na cidade de São Paulo. Tese de doutorado. Faculdade de Filosofia Letras e Ciências Humanas, USP.

TORPEY, John. 2006. Making whole what has been smashed: on reparation politics. Cambridge, Massachusetts, and London: Harvard University Press.

VECCHIOLI, Virginia. 2001. "Políticas de la memoria y formas de clasificación social. Quiénes son las 'víctmas del terrorismo de estado' en la Argentina?” In: Bruno Groppo; Patricia Flier (eds.), La imposibilidad del olvido. Recorridos de la memoria en Argentina, Chile y Uruguay. La Plata: Colección Diagonos, Ediciones Al Margen. Pp 83-102.

VIANNA, Adriana de Resende Barreto. 2014. "Violência, Estado e gênero: considerações sobre corpos e corpus entrecruzados”. In: Antônio Carlos Souza Lima; Virgínia Garcia-Acosta (eds.), Margens da violência. Subsídios aos estudos sobre o problema da violência nos contextos mexicano e brasileiro. Brasília: ABA. Pp 209-237.

Desirée de Lemos Azevedo

PhD in Social Anthropology from PPGAS/UNICAMP, post-doctoral student at PPGS/Unifesp and associate researcher at the Centre for International Migration Studies (CEMI) of the Institute of Philosophy and Human Sciences (IFCH) at UNICAMP.

https://orcid.org/oooo-0002-0266-6258

E-mail: desireelazevedo@gmail.com 